OPEN ACCESS

\title{
Exploring Governance Models of Science \& Research Parks and Related Organizations
}

\author{
Byung-Joo Kang \\ Hannam University, Republic of Korea.
}

Abstract: Recently, investment to basic science has been increased and infrastructure of science and technology has been expanded in developed countries like U.S.A, UK and Japan to foster high-tech industries. Science and research parks are built and under operation to acquire national competitive power and to activate regional economy over the world today. It is argued that more synergy effects are generated when science and research parks are operated in cooperation with related organizations and facilities such as firms, universities, research institutes and governments than it is operated by one organization. The aim of this paper is to develop a governance model of science and research parks. One comprehensive model and three individual governance models were developed according to the structure and relations of industry-science/ research park-supporting organization interactions. When governance model of science and research parks is established and properly managed, national development capacity would be greatly enhanced through the acceleration of technology transfer, industrial production rise and enhancement of efficiency in the area of R\&D and supporting system etc. One of the key factors in building governance system for science and research parks is establishing a control tower that supervises governance system comprehensively and systematically.

Keyword: Science/Research parks, Governance model, Linking agencies between industry production and corporation support, Regional platform, Synergy effect, Network.

\section{BACKGROUND AND NECESSITY OF THE RESEARCH}

As globalization and informationalization expands, civil organizations take over many authorities which were executed by the governments only before, and NGOs around the world are getting considerable influence and the role of the governments are decreases and people's interest in the governance are tremendously increased. Governance is called with many names such as "policy management", "network rule", and "common administration", etc.(Kim Seok-Jun and others

*Correspondence to : Prof. Byung-Joo Kang

Dept. of Urban Planning and Real Estate Studies, Professor of Hannam University, Republic of Korea. E-mail : kbj20@hannam.ac.kr

World Technopolis Review

Copyright $\odot$ World Technopolis Association

CC This is an open-access article distributed under the terms of the Creative Commons Attribution Non-Commercial License(http://creativecommons.org/licenses/by-nc/3.0) which permits unrestricted noncommercial use, distribution, and reproduction in any medium, provided the original work is properly cited
2002) based on areas of interest, but it is not clear yet what the governance actually means in detail. This phenomenon is not confined to Korea only because it seems that the concept of governance has been changing as value system changing.

We are living today in the era of unlimited competition and spending enormous amount of energy to find out alternatives of regional development and to vitalize regional economy. Attracting large companies into their regions was a major policy for the promotion of regional economy in the past, however as each region recognizes that " the very basic element in economic growth is advancement of technology" and excavating and fostering technology intensive SMEs and establishing spontaneous growth base by utilizing universities and research institutes located in the region and building a mutual-assistance structure became a new approach for the local governments. Especially excavating and fostering technology intensive SMEs and commercializing research results from universities and research institutes are one of the most important factors in vitalizing regional economy 
(Luger et al. 1991). This kind of efforts are seen from building science, research parks or technology parks over the world as an alternative of reshaping their industrial structure and vitalizing regional economy.

Many advanced countries such as United States, UK, Germany and Japan are utilizing the capacities of R\&D which are reserved at the technopolis, science park, research parks and technology park located at the universities and trying to use this capacity for the regional development. Plenty of positive evaluations on the effectiveness of building and managing science and research parks for the regional development are visible today. Daedeok Research Park was built in 1970 and characteristics and contents of developing science and research parks were introduced through the "Planning for Technology Belt over the Country" which was initiated at the end of 1980s by the Ministry of Science and Technology and "Planning for the Development of High-tech Industrial Park" which was also initiated at the end of 1980s by the Ministry of Commerce. Hanam Science and Research Park located at Kwangju was built and several science and research parks initiated by the universities in the capital area were built about this time in Korea. Currently there are 18 techno-parks with three types such as model techno-park, late start techno-park and private initiative techno-park. Techno-park project was executed by the Ministry of Know-ledge and Economy to enhance regional technology innovation capability from manufacturing centered economy to knowledge driven economy. The purpose of this project was to build a base for technology innovation to convert growth pattern from material superiority growth approach in the past to efficiency oriented development approach of today.

Recently governance related researches in a few fields were conducted actively in Korea, however no research paper on the governance of science and research parks in detail is found yet. The aim of this paper is to explore a governance model for science and research parks and related organizations that could be applied to any central or local science parks

\section{THEORETICAL REVIEW ON GOVERNANCE}

\subsection{Definition of Governance and Previous Researches}

Recently, there appears variety of concepts on gover- nance which is considered as an alternative of already existing management method of governmental functions. Concepts of governance which are defined by domestic scholars are classified into two kinds such as concept in a narrow sense and a concept in a broad sense. The former concept is distinguished from system of nation and market and it is more voluntary and self-regulated system which exists in civil society. However the later is a form of conciliation appeared as a new type of cooperation and reciprocal action which is totally different from nation, market and civil society in the past.

The focus of discussion in a narrow sense governance concept lies in civil society and regional society and some issues such as social capital and social leadership are more stressed. This concept is more useful when government could not conduct their role in a certain areas but a joint action is necessary. It is said that governance in a narrow sense is useful in dealing with enhancement of civil culture, acceleration of voluntary action, and revision of social base toward democracy (Alcantara 1998).

Meanwhile, concept of governance in a broad sense is a new type of management pattern based on mutual cooperation, which appeared as a boundary between government centered public system and private system disappear(Stoker 1998), and the subjects of governance include variety of persons concerned, nation and market. Partnership and new pattern of cooperation among variety of actors are stressed in a broad sense concept (Gaudin 1998).

If we look at the concepts defined by Korean scholars, building a network as a tool of implementing governance is strongly recommended. Han Sung-Jun(2007) defined that governance is a mutual cooperation system that variety of participants who got an equal position getting out of established hierarchy and forming new network and participating in decision making process. Kim Jung-Yeoul(2000) defined that governance is an alternative management pattern of governmental affairs which includes managements, policies and systems in a broad sense but it is a network for mutual actions among policy makers, which is a replacement of authority exclusively possessed by existing governments in a narrow sense. Meanwhile, Jung Jin Keon(2011) defined that governance is a way of administration or networking system through which public and private organizations and civil groups are spontaneously doing cooperation and mutual interdependence. 
Many foreign scholars also stress networking as a way of governance. Stoker(1998) defines that governance is an organized network, whose features are mutual reliance, exchanging resources and autonomy free from nation and regulations. Pierre(2000) defines that governance is a management system which networks actors and solve public problems by coordinating policies. Peter(2001) defines that governance is a pattern of public decision making, where the interested parties in the institutionalized policies such as central and local governments, civil organizations, and variety of vocational representatives participating in the policy making process and solving the problems.

Governance in this paper is defined that it is an alternative governmental management system or cooperative management system that achieves maximum effect by sharing mutual experience and knowledge through the participation and cooperation from variety of subjects such as governments, firms and civil societies.

\subsection{Advent and Transition of Governance}

Governance was understood as having the same meaning as a government until 1970s, and it was conceived having a relationship with public and institutional system in delivering public services for economic and social development (Stoker 1998). However, the concept of governance was altered from central government centered governing pattern to an alternative concept of executing governmental functions due to the globalization and advent of informationalization, and debates on the limits of government initiative managing system from the late 1970s.

Governance was in charge of central government only in the past but mutual cooperation based on role division among governments, markets and civil societies became more important. It is necessary to have a new type of management system including cooperation with other parties like markets and civil societies to drive national affairs today.

Pierre and Peters(2000) points out three factors in the advent of governance such as expansion of desire from civilians who want to participate in public decision making, advent of new public management policy, and institutionalized participation of individual and group in the process of decision making to enhance the possibilities of success in implementing policies already made. Salet, Thornley, and Kreukels(2003) stress in the comparative research that central government was in charge of protecting national econo- my and providing public goods in the past, however the concept of governance appeared as advent of globalization of economy, liberalization of market and localization in politics from 1980s(Han Sung-Jun 2007).

Cho Sung-Hwan(2005) points out four factors that bring about the advent and transition of governance such as government failure, alteration of management skill, appearance of new liberalism, and globalization. There are several more researches on the advent and transition of governance, but all of the research results could be summarized as having three factors(Han Sung-Jun 2007).

The first factor is decline of role and status of the government. Management approach for expansion period was considered appropriate when large scale unemployment broke out in the era of economic grand panic over the world in 1929, however management skills used by civil groups was applied to government sectors to recover financial crisis and governmental failure in 1970s. As a result, the role and status of the government was considerably reduced up to the level of complementing governmental failure.

The second factor is increase in power and participation of actors except government. As civil society matured due to the advent of era of globalization and informationalization, interests in the governmental policies from NGOs and civil groups were increased and responsibility of those people in community management was also increased. In addition to this, role of the central and local governments was adjusted because of localization and decentralization and power of local governments was strengthened.

The third factor is a necessity of new public management skill. Traditional functions of nation and government were dispersed or transferred to many sectors due to the advent of globalized and informationalized citizens, world-wide environmental groups and multinational firms, other actors outside of the government became to get tremendous power (Pierre and Peters 2000). Under the circumstances, new type of public management system which is totally different from one way or hierarchical control mechanism in the past be-came necessary where variety of actors could work together.

\subsection{Components and Types in Governance 1) Components in Governance}

Components in governance came out with many types 
Table 1. Components and Contents of the Governance

\begin{tabular}{|c|c|c|c|}
\hline Components & Contents & Functions & Domain \\
\hline \multirow{2}{*}{ Actors } & - Sharing experiences and interests through communication & Formation of opinions & \multirow{2}{*}{$\begin{array}{l}\text { Private } \\
\text { domain }\end{array}$} \\
\hline & - Handling common issues \& public opinion & Sharing suggestions & \\
\hline \multirow{2}{*}{$\begin{array}{l}\text { Organization \& } \\
\text { institution }\end{array}$} & $\begin{array}{l}\text { - Area of public institution } \\
\text { - Principle of response, responsibility and efficiency } \\
\text { - Process in institutionalization and exercising authority }\end{array}$ & Policy formation & \multirow{6}{*}{$\begin{array}{l}\text { Public } \\
\text { domain }\end{array}$} \\
\hline & $\begin{array}{l}\text { - Area of informal institution } \\
\text { - Principle of spontaneous participation and cooperation } \\
\text { - Process in exercising influence and deriving mutual agreement }\end{array}$ & Formation of opinions & \\
\hline \multirow{2}{*}{ Process } & $\begin{array}{l}\text { - Design and operate to minimize stress and conflict from diverse } \\
\text { participants }\end{array}$ & Exchanging opinions & \\
\hline & $\begin{array}{l}\text { - Introducing democratic working system to achieve common } \\
\text { goals effectively }\end{array}$ & Collecting opinions & \\
\hline \multirow{2}{*}{ Context } & $\begin{array}{l}\text { - Preparing base for promotion of mutual interchange and coop- } \\
\text { eration } \\
\text { - Conquering dichotomy of autonomy and responsibility in gov- } \\
\text { ernmental and civil society }\end{array}$ & Building cognitive base & \\
\hline & $\begin{array}{l}\text { - Maintaining institutional order and balance } \\
\text {. Establishing conditions for link and coordination between } \\
\text { institutions }\end{array}$ & Building institution & \\
\hline
\end{tabular}

Source: Department of Environment, 2004, Restructuring <Table 3-5> from page 45, ґBuilding environmental governance for the sustainable regional development $\lrcorner$

according to the previous researchers ${ }^{1}$, however four factors are commonly cited from many researches. Those four factors are actors, organization \& institution, process, and context surrounding the structure of governance (Ministry of Environment 2004).

First, actors in governance should be composed of representatives with balance from many different social sectors such as public, private and voluntary sectors. And each representative should be qualified with spontaneity and responsibility to protect and enhance public value. Like this, participants from variety of social sectors who speak for interest groups become to foster capacity to find common tasks, forming public opinions and solve problems together through the process of communication and mutual learning in the governance system.

Second, financial stability and independence should be guaranteed for organization and institution in governance. It is desirable that learning process through communication should be institutionalized to promote close mutual interchange between public and visible institutional sectors and informal and invisible institutional sectors. The process of the governance should be designed elaborately and managed democratically to minimize tensions and conflicts from diverse participants' value and institution and to achieve common goals with effective motivation.

Finally, it is necessary to build a cognitive base to promote

\footnotetext{
${ }^{1}$ Factors of governance are diverse according to the Korean scholars in this field. Choi Byung-Dae(2003) suggests citizen's participation, network and partnership, Kim Jung-Yeoul(2001) argue speciality and autonomy, trust between organizations, and sharing information, Youm Il-Yeoul and Sul Sung-Hyun(2003) mention citizen oriented administration, NGO and specialist, contents and process of the implementation, Park Hee-Bong(2002) suggests trust and participation, horizontal citizen organization, open network, mutual agreement in public decision making, Ok Won-Ho(2001) argue NGO's capacity building as factors of governance. Meanwhile, foreign scholars present different factors of governance, like Newman(2001) social coordination by the network and Hilliard \& Kemp(1999)'s openness and transparency as factors of governance. Some researchers' names such as Youm Il-yeoul, Sung-Hyun, Park Hee-Bong, Ok Won-Ho, Newman and Hilliard and Kemp were recited from other articles but could not find their original references.
} 
mutual interchange and cooperation rather than competition and conflict for the participants who have diverse goals, expectations and habits in one hand and to make an effort to alter social structure to secure public value to stabilize conditions surrounding governance in the context of governance.

\section{2) Types of Governance}

There could be variety of patterns in governance, but it could be classified into two categories such as global governance and local governance based on the size of the objects, and three categories such as market initiative governance, government initiative governance and civil society initiative governance based on the influence from the components.

\section{- Types Based on the Size of the Objects}

Governance is divided into two categories such as global governance and local governance based on the size of the objects.

\section{- Global governance}

Global governance is a management tool needed to handle issues and problems effectively such as environment, human right, woman issue etc. that transcend the national boundary. Since those issues and problems could not be solved by a single country's trial, governance for those problems need a participation form diverse social actors in addition to governmental representatives to cope with global issues.

\section{- Local governance}

Discussions on the local governance was begun after globalization and localization became popular, and in case of western countries, it's necessity was raised to generate a condition for delivery of public services by local governments as welfare nation is dismissed and service from local government depending on central government is being reduced. In addition to this, the necessity was increased considerably as requirements for high level of services for local citizen has increased and as policy issues that must be solved locally appeared. Under this circumstance, local governments were required to alter their role from service provider to service enabler to activate regions and to enhance quality of life, and local governance was generated in this process.

- Types based on the influence

Governance is classified into three categories such as market initiative governance, government initiative governance and civil society initiative governance based on the influence of the subjects that compose nation, market and civil society.

\section{- Market initiative governance}

Influence of the capitalist market became reinforced and content of the government and administration of individual country got the influence from globalization in economy. Especially, as diverse rounds such as WTO, TR, BR, GR etc. made whole world into one unit, firms and citizens in addition to a countries got the influence of world wide capital. Accordingly, governance in individual country became more market oriented way to a certain degree.

Mutual interaction between diverse persons interested is stressed in market initiative governance with horizontal, coordinative and participatory relationship than traditional government. Privatization is stressed in market initiative governance to solve inefficiency from big government and market governance aspire small and efficient governmental structure. The aim of privatization is to enhance range and quality of services by transferring governmental functions to private sectors and to maximize economic efficiency by reducing governmental expenditures (Gilmour and Jensen 1998). However, it is criticized that public activities and related authority which was in charge of government before could be reduced or declined because those activities and authorities were handed over undemocratic and irresponsible parties.

\section{- Government initiative governance}

Government initiative governance was begun to establish an efficient and effective management system to solve the problems arising from a hierarchical administrative system by making diverse persons interested participate in the decision making process. Since government initiative governance is built with a spirit of enterprise or a new public management system, a harmony between government and market is a key task. It is not a big deal applying entrepreneurship or private management system to the government because governments in United States or Europe were already settled down on the principles of capitalism and democracy. However, a harmony between government and market is a fundamental problem to solve and it could be a core element for governance in the continental countries. The aim of government initiative governance is to revise management system by introducing a high creativity, competence, and rapid response and adaptability that private companies have into the governmental management system to cope with the changes of the society (Kooiman and Van Vliet 1993).

\section{- Civil society initiative governance}

Functional and management side is emphasized in market and government oriented governance. For an example, weak civil society is a prior condition in the 'partnership' that is frequently used in both governance because an economic 
motive of efficiency to insure investment capital and a strategic motive of activating governmental functions efficiently are existed there together. However aggressive participation of citizen is necessary to make a governance active and to accelerate interchange of information and to bestow legitimacy on the decision making process.

It is necessary to build a governance base rooted on the development of civil society because trust from participants is a key factor in the true governance. It is not necessary for governance to be established based on public authority, but it is very necessary to build a communication oriented governance system not as an object or a guest of governance but with citizen's voluntarily participations.

\section{SCIENCE AND RESEARCH PARK AS AN OBJECT OF GOVERNANCE}

\subsection{Current Situations and Background of Building Science and Research Parks}

There is no standardized definition on the science and research park, which is developed with various types from country to country to enforce economic development through the technological innovation. But in many cases science and research park is a place where many facilities for $\mathrm{R} \& \mathrm{D}$, start-ups and incubation, training, supporting function are located to conduct joint R\&D projects and technology transfer for universities, public research institutes and private research labs to support high-tech industries and to accelerate regional economic development. However there is a difference in components of science parks from park to park such as only R\&D function is carried out in one park and only facilities for experiment and production are agglomerated in another park.

Building a science and research park was driven or examined as a tool of regional development from many regions in the world as Silicon Valley was evaluated as a successful model of economic prosperity. This kind of activation in building science and research parks is due to the conceptual development from industrial park in the past to research and technology parks or high-tech industrial parks in the transition process from manufacturing centered society to knowledge and information based society.

Many advanced countries began to introduce science and research parks affirmatively as an engine of regional economic development as economic stagnation happen, world widely at the late 1970s. Building a science and research park was begun by the universities in the beginning with a purpose of accelerating industry university cooperation by locating industrial research labs in the excellent engineering university campus. However, as time passed, science and research parks became a place to conduct multiple functions such as supporting start-ups, exchanging information and providing education and training.

Many regions in the world today try to build science and research parks to reshape their industrial structure with more high technology centered industries to survive in the era of globalization and informationalization. Because enhancement of international competitive power and activation of regional economy are achieved through the establishment of science and research parks, acceleration of technology innovation and synergy effect is obtained through the networking industries, research institutes and universities with putting science and research park at the center.

There are currently about 540 science and research parks enrolled in IASP (International Association of Science Parks) and AURRP(The Association of University Related Research Parks) in 2012 in the world. However, more than 1300 parks are estimated to exist if take a report into account that there are more science and research parks not registered than registered. U.S.A. holds about 140 parks, France about 60 parks and United Kingdom about 50 parks (AURRP 2013).

Apartment type space rent, business incubation facilities and programs, medical facilities, hotel or convention center, high speed intelligence network, leasure and convenience facilities are ubiquitous in any science and research park.(www. industryweek.com).

Daedeok Research Park has 40 years history and there are 18 techno-parks(or industrial technological park) with three kinds in Korea today. There are 6 model techno-parks built by model techno-park builder in Songdo, Kyunggi, Daegu, Kyungbuk, Kwangju, and Chungnam and 10 late start techno-parks built by local autonomous entities in Chungbuk, Jeonbuk, Jeon-am, Kangwon, Kyungnam, Oulsan, Busan, Pohang, Daejeon and two private initiative techno-parks in Kyunggi and Seoul.

\subsection{Classification of Science and Research Parks Based on Management Pattern}

Management pattern of science and research parks provides considerable implications in establishing a governance model to build in this paper. Science and research parks could be classified into three types such as university and 
research institute initiative parks, government initiative parks and corporation initiative parks from building site and managing subject point of view.

\section{- University and research institute initiative park}

This type of park is established to activate regional economy by transferring accumulated research results at the universities and research institutes to the firms. This type of park is developed with small scale or building type because of university's insufficient financial capacity and is operated with technology and innovation oriented pattern or R\&D centered pattern in functional aspect, and incubation center for technology centered start-up and center for technology innovation are major facilities in this type of park.

\section{- Government initiative park}

This type of park is classified into two categories again such as central government initiative parks and local government initiative parks. Central government initiative parks aims to enhance national competitive power in science and technology in the global context and to build a big park with a huge budget and try to activate the park by bestowing the first priority to central government invested research institutes to attract them into the park. Local government initiative park is built based on technology potential in the region and local governments that have a high desire in technology innovation and to build a science park on the land they possess and this type of park is built to activate regional economy through technology based start-ups of local SMEs and acceleration of technology innovation from existing firms.

\section{- Corporation initiative Park}

This type of park is built based on the real estate development approach. A real estate corporation builds a science and research park with land and capital they posses and developed lots in park are sold or rented. This type of park is found at metropolitan cities where land or building price is very high and the success factor of this kind of park is low price of rent for the lands and buildings.

Contents and characteristics of three types of parks are summarized in $<$ Table $2>$ below.

Table 2. Classification of Science and Research Parks Based on Management Pattern

\begin{tabular}{|c|c|c|c|}
\hline \multicolumn{2}{|c|}{$\begin{array}{l}\text { Management } \\
\text { Pattern }\end{array}$} & Management Pattern and Characteristics & Examples \\
\hline \multicolumn{2}{|c|}{$\begin{array}{l}\text { University / } \\
\text { Research Institute } \\
\text { Initiative }\end{array}$} & $\begin{array}{l}\text {-This type of park is built with excellent engineering universities and research institutes and } \\
\text { aims to activate regional economy by transferring research results accumulated at universities } \\
\text { and research institutes to the firms. }\end{array}$ & $\begin{array}{l}\text {-Boston } \\
\text { 'Route } \\
128 \text { ' }\end{array}$ \\
\hline \multirow{2}{*}{$\begin{array}{l}\text { Govt. } \\
\text { Initiative }\end{array}$} & $\begin{array}{l}\text { Central } \\
\text { govt' }\end{array}$ & $\begin{array}{l}\text {-This type of park is developed with large scale to enhance national competitive power in sci- } \\
\text { ence and technology, and park is developed by bestowing the first priority to central govern- } \\
\text { ment invested organizations to attract them into the park. Weak linkage with the regional } \\
\text { economy is one of the problems this type of parks have in many cases. }\end{array}$ & $\begin{array}{l}\text {-Sophia } \\
\text { Antipolis }\end{array}$ \\
\hline & $\begin{array}{l}\text { Local } \\
\text { govt' }\end{array}$ & $\begin{array}{l}\text {-This type of park is built on the land owned by local government and aims to activate region- } \\
\text { al economy through the activation of technology based start-up of SMEs and acceleration of } \\
\text { technology innovation from existing firms. }\end{array}$ & $\begin{array}{l}\text {-Research } \\
\text { Triangle }\end{array}$ \\
\hline \multicolumn{2}{|c|}{ Corp. initiative } & $\begin{array}{l}\text {-This type of park is developed by the real estate corporation and developed lots of park are sold } \\
\text { or leased. This type of park is useful in metropolitan cities where land and building price is high. }\end{array}$ & $\begin{array}{l}\text {-Silicon } \\
\text { Valley }\end{array}$ \\
\hline
\end{tabular}

Source: Kang Byung-Joo(2002), “A Research on the Establishing Development Models for Science and Research Parks,” restructured from P.25 
Table 3. Contents of Governance Based on Types of Science/Research Parks

\begin{tabular}{|c|c|c|c|}
\hline Category & University initiative park & Government initiative park & Corporation initiative park \\
\hline Visions & $\begin{array}{l}\text { - Activation of regional economy } \\
\text { by transferring research results } \\
\text { accumulated at the universities }\end{array}$ & $\begin{array}{l}\text {-Enhancement of national science } \\
\text { and technology capacity } \\
\text {-Activation of technology cen- } \\
\text { tered start-ups }\end{array}$ & $\begin{array}{l}\text {-Selling and renting land and } \\
\text { buildings with low price where } \\
\text { those prices are high }\end{array}$ \\
\hline Goals & $\begin{array}{l}\text { - Creation of new research out- } \\
\text { comes } \\
\text { - Transferring research results to } \\
\text { firms }\end{array}$ & $\begin{array}{l}\text {-Enhancement of science and } \\
\text { technology capacity } \\
\text {-Activation of start-ups Technol- } \\
\text { ogy innovation }\end{array}$ & $\begin{array}{l}\text {-Providing low priced land and } \\
\text { buildings } \\
\text {-Technology innovation }\end{array}$ \\
\hline $\begin{array}{l}\text { Persons } \\
\text { interested }\end{array}$ & $\begin{array}{l}\text {-University neighboring SMEs, } \\
\text {-Universities } \\
\text {-Research institutes } \\
\text {-Local governments and national } \\
\text { organizations }\end{array}$ & $\begin{array}{l}\text {-Local governments and } \\
\text { national organizations } \\
\text {-Citizen groups } \\
\text {-Universities } \\
\text {-Large enterprises } \\
\text {-Large enterprises-Local SMEs }\end{array}$ & $\begin{array}{l}\text {-Local SMEs } \\
\text {-Financial organizations } \\
\text {-Real estate developers } \\
\text {-Supporting organizations for } \\
\text { SMEs }\end{array}$ \\
\hline Hub & University & Government & Corporation \\
\hline $\begin{array}{l}\text { Expansion } \\
\text { order }\end{array}$ & $\begin{array}{l}\text {-University is the center and } \\
\text { expanded to research institute, } \\
\text { central government, local gov- } \\
\text { ernment, firm order }\end{array}$ & $\begin{array}{l}\text {-Government is the center and } \\
\text { expanded to local firm, universi- } \\
\text { ty, research institute, firm and } \\
\text { citizen group order }\end{array}$ & $\begin{array}{l}\text {-Corporation is the center and } \\
\text { expanded to central government, } \\
\text { local government, financial org. } \\
\text { university, and supporting org. } \\
\text { order }\end{array}$ \\
\hline $\begin{array}{l}\text { Major tool of } \\
\text { governance }\end{array}$ & $\begin{array}{l}\text {-On-line and off-line are evenly } \\
\text { used }\end{array}$ & $\begin{array}{l}\text {-Off-line is the major and on-line } \\
\text { is used as a replacement }\end{array}$ & $\begin{array}{l}\text {-On-line is the major way of gov- } \\
\text { ernance }\end{array}$ \\
\hline
\end{tabular}

\section{BASIC GOVERNANCE MODEL OF SCIENCE/RESEARCH PARK AND RELATED ORGANIZATIONS}

\subsection{Characteristics and Contents of Governance Model}

It is nearly impossible to create a standard governance model that could be applied to any science and research parks in the world because various elements are combined together in composition and management of governance. Therefore, governance system should be created for a specific organization to fit for social situations and characteristics of the corresponding organization. In this context, establishment of governance model as an alternative management tool to lead development of science and research parks, regional conditions and characteristics of relevant science/ research park should be analyzed in advance.
Governance patterns of science/research parks are classified into three categories in general such as government initiative governance, university initiative governance and corporation initiative governance if regional conditions and characteristics are excluded. Contents of governance based on types of science/research parks are compared in $<$ Table $3>$.

Visions and goals of governance are different each other from park to park. Vision and goal of university initiative governance are transferring research results accumulated at universities to firms and activating regional economy, but enhancing scientific competitive power and activating startups are goals of government initiative governance. Meanwhile, providing land and buildings to science/research parks with a reasonable price are goals of corporation initiative governance.

If we look at the governance from interested party' point 
of view, neighboring small and medium sized enterprises, local governments and national organizations are the objects of university initiative governance, but financial authorities, real estate developers, supporting organizations for the small and medium sized enterprises are the objects of corporation initiative governance. On-line and off-line are evenly used in university initiative governance, meanwhile off-line is mainly used in government initiative governance and on-line is mainly used in corporation initiative governance.

\subsection{Development Process of Governance Model for Science/Research Parks}

Various types of governance model for science/research parks are possible according to how to set up relationships among actors, organization and system, and operation process. Governance models are classified into three types in Triplex Helix governance and three types are static model, liberalism model and liberalism model according to structure of relationship among university, industry and government which are actors in innovation. Static model is a model where government controls universities and industries, liberalism model is a model where three actors behave independently with a clear boundary among them, and liberalism model where three actors have a horizontal network and it is an ideal type in Triplex Helix governance.

Actors, who are the subjects in governance system, have horizontal relationship in this paper and title of each governance model was given to show the function and role of the organization that is the center in the governance. Governance system is designed based on mutual relationships between actors who are in horizontal position and contents of works executed by them. Three governance models developed in this paper were established with five components such as objectives, analysis of actors, process of project execution, organization and system, and way of governance.

To explore governance models, analysis of subjects in governance system should be conducted in the first place. Science/technology parks were understood in the functional point of view in this paper and it was assumed that science/research park is a place where R\&D function is mainly carried out and industrial production function and industry supporting function is efficiently performed. In this paper science/research parks are supposed to contribute to the growth of regional economy with a tight linkage of many other organizations, and in exploring a governance model, related organizations are included.

\subsection{Basic Model of Science/Research Parks and Related Organizations}

Science/research parks are places where R\&D function is mainly carried out and industrial production function and industry supporting function is efficiently performed. To connect three functions of science/research parks such as R\&D function, industrial production function and industry supporting function, supporting organization that directly provides technology, production, marketing, legal consultancy to the firms is also a key element. R\&D function is performed by an aggregate of various applied research facilities such as ERC, SRC, RRC and TIC, and industrial production function is carried out through strategic industries and linkage industries and industry supporting function is conducted by various public and private production supporting organizations (technology supporting, marketing, and distribution) and by an aggregate of service industries. To activate science/research parks, regional platform that takes care of indirect linking function such as window and brokering is one of the essential functions in science/research parks also.

Establishment of institution or system which links directly or indirectly three functions such as industrial production, $\mathrm{R} \& \mathrm{D}$, and industry supporting has very important meaning in basic governance model of science/research parks. Direct linking organization is an organization which links industrial production and R\&D or industrial production and industry supporting function. Science/research park, consortium among industry, university and research institute, organization of technology transfer, organization solving difficult technologies(ex; Research Institute of Production Technology) are linking organizations for industrial production and R\&D. Korea Industrial Park Corporation, supporting teams from local governments, Center for Comprehensive Support for SMEs, CROs providing technology market information are linking organizations for industrial production and industry supporting function. Regional platform is an indirect linking organization which performs a role of linking industrial production and R\&D and industry supporting by carrying out brokering function and cooperating program by on/off lines.

Basic governance model of science/research park and related organizations are conceptualized like $<$ Fig. $1>$ below. 


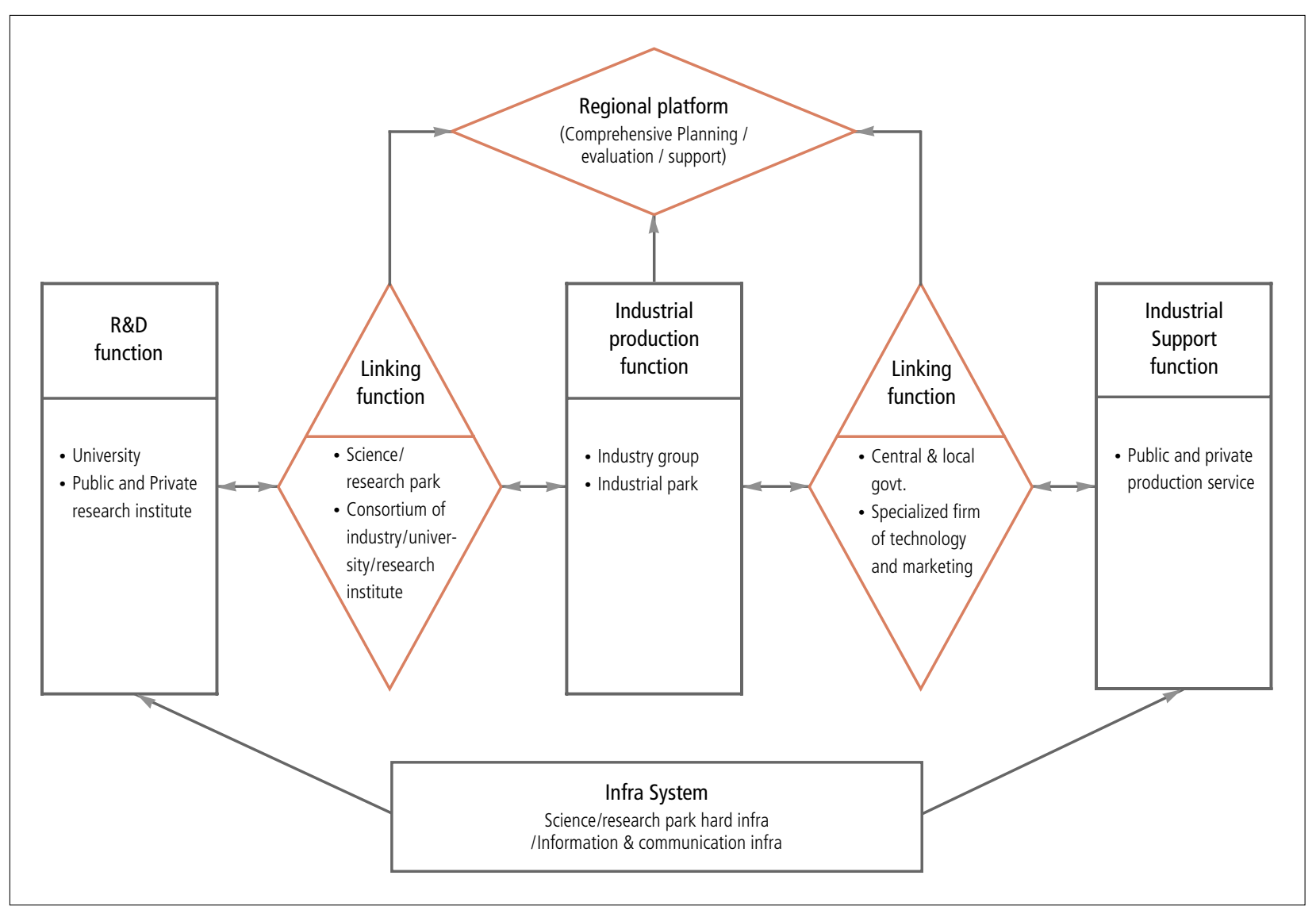

Fig. 1. Basic Governance Model of Science/Research Park and Related Organizations

\subsection{Contents and Types of Science/Research Park and Related Organizations}

Main contents in establishing governance model of science/research parks and related organizations are building three types of governance model such as (1)Linking organization centered governance model for R\&D with industrial production (2)Linking organization centered governance model for industrial production with industry supporting and (3)Linking organization centered governance model for regional platform with infra-system.

\section{(1) Governance model for technology development and transfer}

Speed in technological shift and competitive power of a firm in the global market of any country are not depend on only R\&D or other technological activities but depend on how firms in the region manage all the available resources efficiently. Accordingly, the focus of an efficient governance system should be put how to achieve a rapid technology innovation by appropriately combining limited resources available in the region and technological adaptability and capacity of development existing in the region.

Linking organization for R\&D with industrial production centered governance model is a governance system that links R\&D system such as universities, public research institutes, private firm research institutes, ERC/SRC, RRC, TIC, etc. with industrial production system such as a group of company and industrial parks. Science/research parks, regional foundation of high-tech industry promotion, consortium of industry, university and research institute is correspond to this kind of linking organization. It is required that linking organization should develop and expand cooperation program and policy tool to build a organic and harmonious governance, and should make a harmonious supply and demand system to circulate R\&D and technologies among suppliers and demanders. 


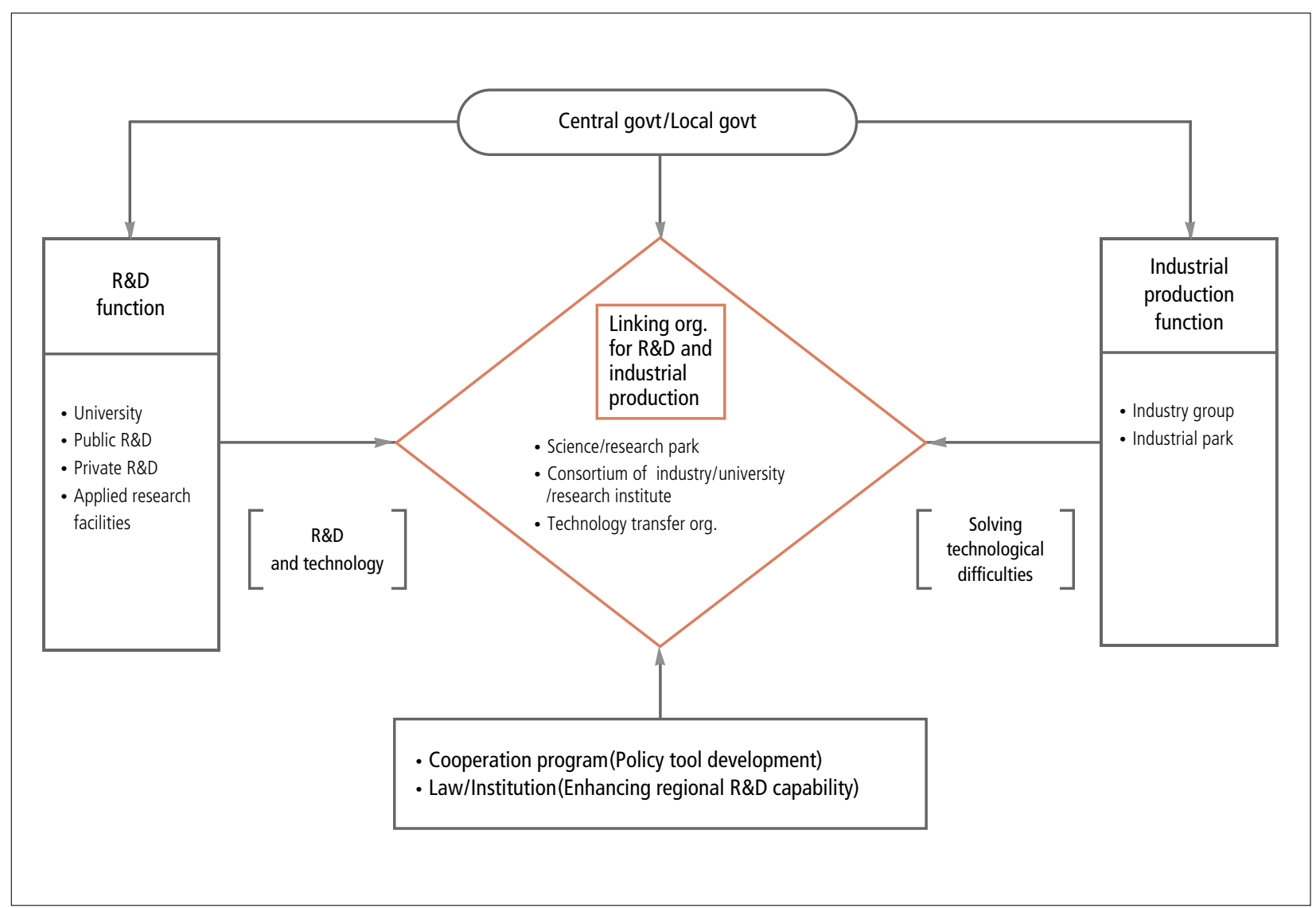

Fig. 2. Governance Model for Technology Development and Transfer

Central government and local government should try to attract public and private research institutes and try to supplement insufficient facilities and functions in fostering strategic industries in the region, and making governance smoothly through the arrangement of related laws and institutions is also an important task for the governments. Meanwhile, it is necessary to try to foster forward and backward industries based on regional strategic industries to maximize industrial innovation capability in the region in relation with building industrial production system, and it is very important also to establish a cooperative network between firms and consortium among industries, universities and research institutes.

\section{(2) Governance model for industrial production}

Silicon Valley in U.S.A. is a representative example of governance model for linking organization for industrial production with industry supporting in the region which make a competitive power of the company. So many enterprises are agglomerated around Stanford University in Silicon Valley, and so many enterprise related centers such as basic research institute, funding company, supporting organization for production service, supporting center for facilities, supporting center for education are agglomerated and those centers contribute to activate start-up activities and to increase innovation capability of already existing enterprises.

Since industry related organizations such as research institutes, universities, centers for production service are spread over the city in metro cities in Korea, it is more effective to achieve a synergy effect by maximizing human and physical resources from the region through the enforcement of active governance and cooperation between already existing firms and by generating innovation through mutual interaction among various organizations rather than expanding physical base for industrial support(Shin Chang-Ho 2007).

Linking organization centered governance model for 


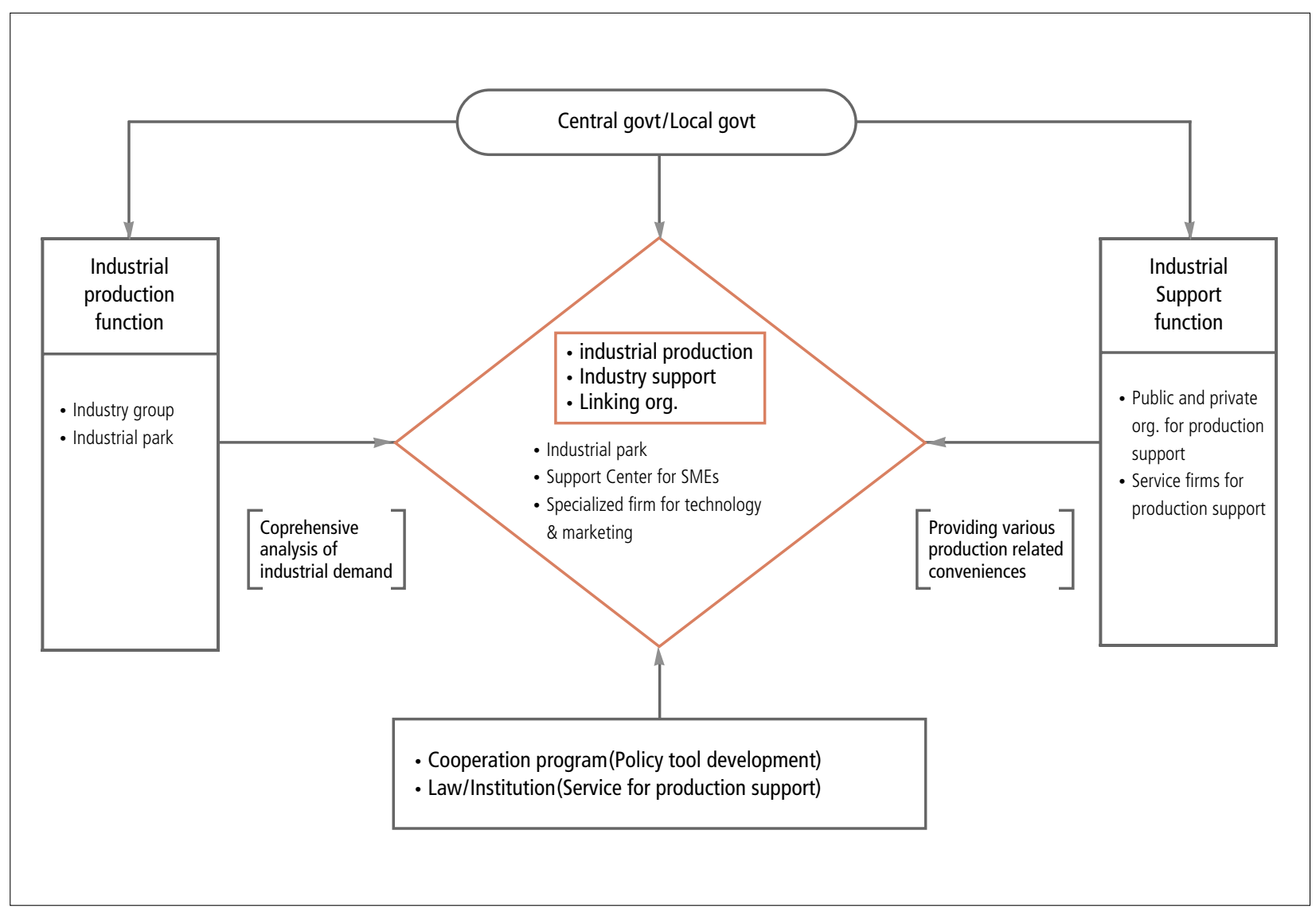

Fig. 3. Governance Model for Industrial Production

industrial production with industry supporting is a governance system which connects industry supporting function such as public and private production organization, production supporting service etc, with industrial production function such as a group of firms and industrial parks etc. Corporate of Industrial Park, Supporting Center for SMEs, CROs specialized in marketing and providing technology and market information are correspond to this kind of linking organization, and it is required that this linking organization should develop and expand cooperation program and policy tool to build an organic and harmonious governance for both functions.

It is necessary for linking organization to identify industrial demands comprehensively through the consistent route and conduct systematically a role of providing many kinds of conveniences in carrying out industrial activities that are needed from industry supporting organizations. It is important for central and local governments to attract public and private production supporting facilities and many kinds of manufacturing related services which are in sufficient in relation with fostering strategic industries to the region. It is also needed to arrange laws and systems which interrupt the establishment of harmonious governance for industrial sector and industry supporting sector.

\section{(3) Governance model for regional platform}

It is needed for central and local governments to prepare a long term and a short term strategies in building regional platform and in establishing a governance system for linking organizations. In medium and short term point of view, trying to supplement insufficient facilities, functions and human resources through the cooperation between local governments and regional networking is necessary and securing finance from the central government is an essential element when cooperation projects between the regions are proceeded. It is desirable for central and local governments to make 
regional platforms secure finance and render them authority and responsibility to perform planning and supporting infrasystem (R\&D, industrial production, industry support) based on their independent financial basis in the establishment of governance model for linking organization for regional platform with infra-system. Since regional platform has a characteristics of specialized organization, it is desirable for central and local governments give regional platforms autonomy in managing their organizations and confine them carry out coordinating and supporting functions only.

To establish a smooth regional platform centered linking system for industries, universities, research institutes and industry supporting organizations in the region, the most urgent job is concentrating all the innovative information transmitted from the innovative subjects in one place and managing information systematically. In spite of agglomerations of supporting organizations such as universities, research institutes, a group of production service, etc. in Seoul or metropolitan cities, they did not contribute to the industrial activities because related organizations were dispersed over the city and a smooth linking system was not built at all.

Two functions should be performed in the regional platform in this model. The first function is establishing a data base for the information of supporting organizations which provide a support to $\mathrm{R} \& \mathrm{D}$, technology, management information, education \& training, event \& exhibition, start-up incubation etc. and data base for supporting projects and outside specialists. The second function is exchanging and providing variety of information by connecting outside information networks. To provide a real service to industry supporting organizations such as industries, universities, research institutes, industry support organizations, it is necessary not only concentrating and managing innovative information but also introducing supporting organizations and supporting projects through the establishment of institutional linking system.

Regional platform could supplement weakness that on-line governance has by preparing a meeting place between innovation subjects in the region by way of off-line style governance, and should make innovative subjects in the industries, universities, research institutes meet and exchange their information and opinions each other more frequently. To activate meetings, various space for the meeting between innovative subjects should be provided and opportunities of contact among related persons through various events, seminars, and symposium should be increased.

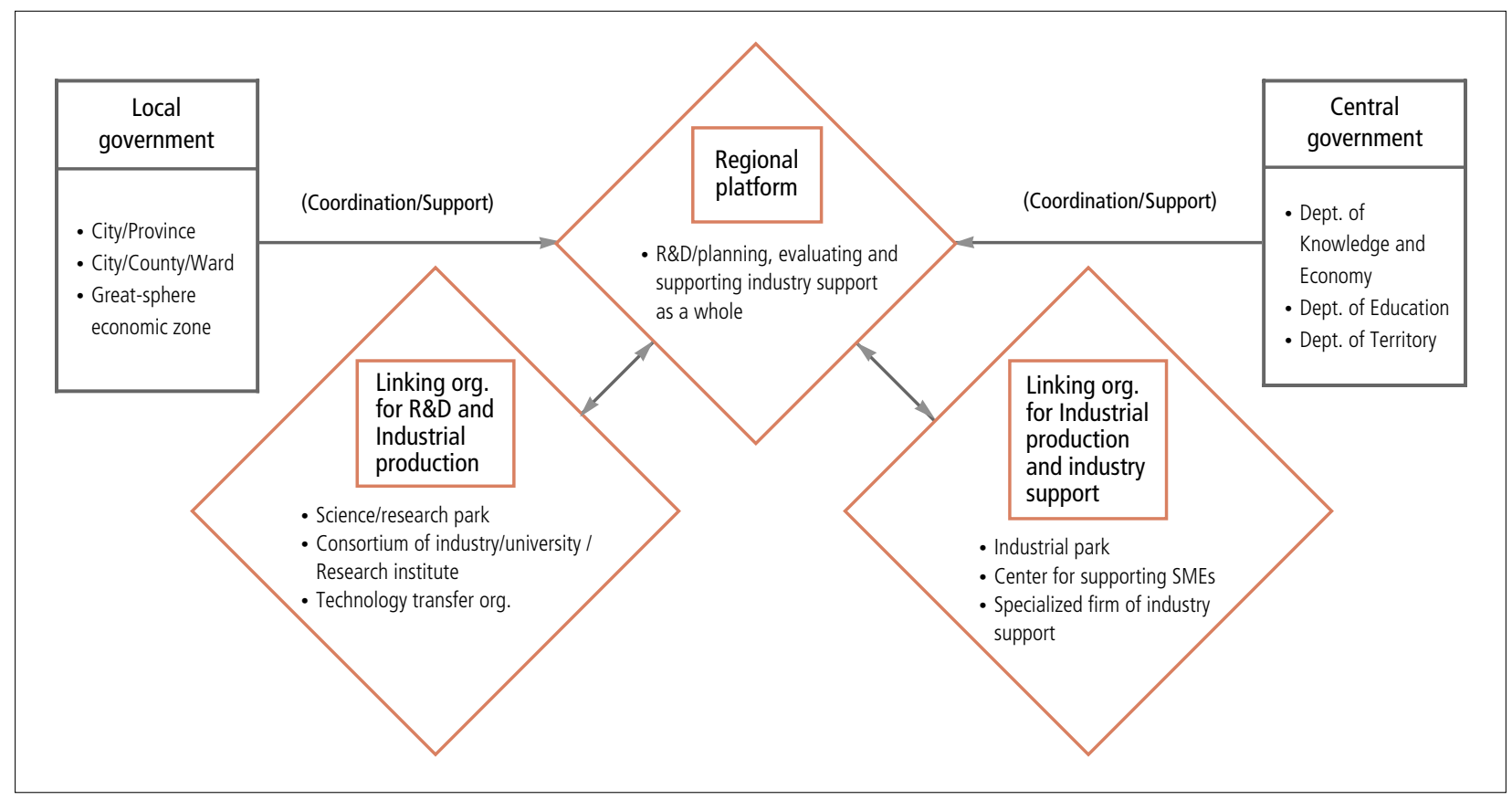

Fig. 4. Governance Model for Regional Platform 


\section{CONCLUSION}

World is changing quickly toward knowledge based society today but better tomorrow is not guaranteed only with a cheap price of labor force and land. A common feature of economically prosperous regions is they have science and technology that other regions does not have and they try to build science and technology parks based on what they have. There are about 200 science/technology parks in U.S.A. including Boston Route 128, Silicon Valley, Research Triangle Park, and so many high-tech industrial parks and technology parks initiated by local governments and supported by central governments compete each other seriously in Asia such as China, Taiwan, India, Singapore, Malaysia etc. It is found from many materials that science/technology park contributes to regional economic growth enormously and eventually to national development. In spite of serious competition in building science parks, nearly no research is visible on this subject and desirable governance models for science/research parks and related organizations.

Various types of governance model for science/technology parks and related organizations are possible according to view points. Science/technology parks were understood in the functional point of view in this paper and it was assumed that science/research park is a place where R\&D function is mainly carried out and industrial production function and industry supporting function is efficiently performed. In this paper science/research parks are supposed to contribute to the growth of regional economy with a tight linkage of many other organizations, and in establishing a governance model, related organizations are included. After a careful examination of three functions such as industrial production, R\&D, and industry supporting and a function of direct and indirect linking organizations that help those three functions, a governance model of science/research parks and related organizations was established in this paper. Four governance models are suggested in this paper.

Firstly, in a basic governance model of science/research parks and related organizations, three functions such as industrial production, R\&D and industry supporting and organizations and institutes which link those three functions directly or indirectly are analyzed. Direct linking organizations are composed of linking organizations for industrial production with R\&D such as science/research parks and authorities for technology transfer and linking organizations for industrial production with industry supporting such as
Korea Corporation of Industrial Park, Comprehensive Support Center for SMEs. Direct linking organization is a regional platform which links industrial production function, R\&D function and industry supporting function indirectly by carrying out brokerage function and cooperation programs with on/off forms.

Secondly, linking organization centered governance model for R\&D with industrial production is a governance system that links R\&D system such as universities, public and private research institutes with industrial production system such as a group of company and industrial parks. This linking organization is corresponded to organizations for technology transfer such as science/research parks and foundation for promotion of regional high-tech industries. The main job of this linking organization is to develop and expand cooperation programs and policy tools for the sake of establishing a good governance system for both functions (R\&D and industrial production).

Thirdly, linking organization centered governance model for industrial production and industry supporting is a governance system which connects industry supporting function such as public and private production organization, production support service etc, with the industrial production function such as a group of firms and industrial parks etc. Corporation of Industrial Park, Supporting Center for SMEs, CROs specialized in marketing and providing technology and market information are correspond to this kind of linking organization. It is required that this linking organization should develop and expand cooperation program and policy tool to build an organic and harmonious governance for both functions.

Lastly, in the linking organization for regional platform with infra system centered governance model, it becomes an important task to manage linking organization systematically for R\&D and industrial production with linking organization between industrial production and industry supporting for the smooth link among industrial sectors, universities, research institutes and industry support organizations in the region with putting regional platform the center.

Even if governance system in science/research parks and related organizations did not get a spotlight yet, it is a very important area. When governance is established and properly operated, efficiency in acceleration of technology transfer, industrial production, sales, delivery and storage will be greatly increased and effectiveness in the field of R\&D, production and supporting will be enhanced, and eventually 
national development capability will be increased also. The role of central and local government is very important at the beginning stage of governance establishment because expenditures are greatly bigger than revenue at this stage. Central government should prepare a basic plan of establishing a governance model for science/research parks and related organizations and local government should request industries and related supporting organizations to participate in building a governance system. One of the serious problems in establishing a governance system for science/research parks and related organizations is that there is no organization that handles this matter comprehensively and systematically. Building a regional platform in developing countries is necessary as was needed in advanced countries in the long term point of view.

\section{REFERENCES}

Alcántara, C. H.(1998) "Uses and abuses of the concept of governance," International Social Science Journal 50(155): 105-13.

AURRP(2013) About AURRP, web site www.aurp.net. The Association of University Related Research Parks.

Cho, S-H(2005) "New Understanding of Governance" Research on National Policies, 19(2): 47-68, [in Korean].

Gaudin, J. P.(1998) "modern governance, yesterday and today: some clarifications to be gained from French governmentpolicies," International Social Science Journal 50(155): 145-57.

Jung, K-H.(2002) "Experiment of Governance and Systemization of Green Value through Agenda 21," Research Institute for Wind and Water, Green Politics, Green Nation in Korea (Seoul: DangDae Press), [in Korean].

Jung, J-K., and Kim, C-K.(2011) "A Study on the factors of Governance in Urban Planning System," Research on Local Administration 25(4): 53-84, [in Korean].

Kang, B-J.(2004) "A Study on the Establishing Development Model for Research Parks," Journal of Technology Transfer 29:203-10.

Kim J-Y.(2000) "Future and Governance of the Government New Public Management and Political Network," Korean Public Administration Review 34(1): 21-39, [in Korean].
Kim S-J, et al.(2002) Understanding of Governance, (Seoul: DaeYoung-Moonhwa Press, [in Korean].

Kooiman. J., and Van Vliet, M.(1993) "Governance and Public Management," in K. A., Eliassen and J, Kooiman, eds. Managing Public Organization(London: Sage Publications).

Luger, M., and Goldstein, H.(1991) Technology in the Garden: Research Parks and Regional Economic Development(Chapel Hill: The University of North Carolina Press).

Ministry of Education and Science and Technology(2008) $A$ Study on the Management System and Supporting Method of Science and Research parks.

Ministry of Environment(2004) A Method of Establishing Environmental Governance for the Sustainable Regional Development.

Ministry of Science and Technology(2007) Efficient Management Strategy for Local Science and Research Parks.

Mothe, John de la(2001) "Knowledge, Politics and Governance", Science, Technology and Governance(ed.), John de la Mothe(ed.)(New York, NY: Continuum).

Peter, J.(2001) Governance in Western Europe, SAGE Publication Ltd.

Pierre, J.(1999) "Model of urban governance: the institutional dimension of urban politics," Urban Affairs Review 34(3): 372-96.

Pierre, J., and Peters, B.G.( 2000) Governance, Politics and the State (New York, NY: Macmillian Press).

Rhodes, R. A. W.(1996) "The New Governance: Governing without Government," Political Studies 44(4): 652-67.

Saxenian, A.(1985) "Silicon Valley and Route 128: Regional Prototype Or Historic Exceptions?" In M. Castells, ed. High Technology, Space, and Society (Beverly Hills: Sage Publications).

Saxenian, A.(1999) Regional Advantage: Culture and Competition in Silicon Valley and Route 128 (Cambridge, MA.: Harvard University Press).

Seo S-T.(2008) "A Study on the Reorganization of Urban Planning System attendant upon Governance Shift", Journal of the Korean urban Management Association 21(1): 85-105, [in Korean].

Shin, C-H.(2007) A Method of Establishing Industry Support Base for Seoul Metropolitan City (Seoul: Research Institute for Policy Development of Seoul Metropolitan City), [in Korean]. 
Skolnikoff, E. B.(2001) "International Governance in a Technology and Governance," in edited by John de la Mothe Science, Technology and Governance, Science, technology, and the International Political Economy Series(New York, NY: Continuum).

Stoker, G.(1998) "Redefining Local Democracy. In Lawrence Pratchett and David Wilson (eds.)," Local Democracy and Local Government (Basingstoke: Macmillan Press).

UKSPA (1991) The Role of Science Park in the Promotion of Innovation and Transfer of Technology (Birmingham, U.K.: UK Science Park Association).

\section{GENERAL REFERENCES}

Bae, U-H.(2003) "Experiment for Governance: Theory and Reality of Network Organization - with reference of Foundation for Rehabilitation of DaeChung-Ho," Journal of Korean Administration Association 37(3): 107-29, [in Korean].

Castells, M, and Hall, P.(1994) Technopoles of the World: the Making of the 21st Century Industrial Complexes (London; New York, NY: Routledge).

DiGaetano, A., and Lawless, P.(1999) "urban governance and industrial decline: agendas in Birmingham and Sheffield, England, and Detroit, Michigan, 1980-1997," Urban Affairs Review 34(4): 546-77.

Gilmour, R. S, and Jensen, L. S.(1998) "reinventing government accountability: public functions, privatization, and the meaning of 'state action'," Public Administration Review 58(3): 247-58.

Han, Sung-Jun(2007) "A Study on the Theoretical and Practical limits from Discussion of new Governance", Journal of Korean Administration Association 41(3): 95-116, [in Korean].

Juma, C., et al.(2001) "Global Governance of Technology: Meeting the Needs of Developing Countries", Int. J. Technology Management 22(7/8): 629-55.

Jung, B-C.(2007) Science and Technology Governance and Groping of Political Paradigm for Civil Society, Science and Technology Policy Institute, [in Korean].

Kim J-H., et al.(2009) Management Examples and Direction of Policy for University Initiative Science Park, Korea Institute of Economy and Technology, [in Korean].
Massey, D., Paul Quintas, and David Wield.(1992) High-Tech Fantasies: Science Parks in Society and Space (London: Routledge). 